\title{
The Effect of Population Density and Sex Ratio on the Mortality of Juvenile Laboratory Mice in Experimental Populations *
}

\author{
Anna KOZAKIEWICZ
}

\begin{abstract}
Kozakiewicz A., 1976: The effect of population density and sex ratio on the mortality of juvenile laboratory mice in experimental populations. Acta theriol., 21, 25: 339-350 [With 3 Tables \& 5 Figs.].

Eighteen populations of the laboratory mouse (Mus musculus L.) were reared for 1 to 2 months in wooden cages. The population numbers were 100,60 or 20 individuals per cage with the ratio of males to females equal to $1: 1,1: 2$ or $1: 4$. Food and water were supplied in excess. Each day the females were examined and classified into 3 categories: pregnant, lactating and others. For each day percentage mortality of young mice was calculated. Moreover, observations were made on the transfer of the litter by females. It was found that the frequency of this transfer is directly proportional to the number of females in a population. When the number of males in the population was small (up to 12) a direct relationship was observed between the frequency of transfer of young mice by females and mortality of young mice. At higher number of males such relationship was not found but then the frequency of transfer was very high and mortality approached $100 \%$. At increased population numbers and at relatively high proportion of males a higher number of non-lactating females participated in the transfer of young mice.

[Dept. Zool. \& Ecol., Warsaw Univ., Krakowskie Przedmieście 26/28, 00-325 Warszawa, Poland]
\end{abstract}

\section{INTRODUCTION}

The principal mechanisms regulating animal number and production in confined populations include reproduction and mortality. For this reason studies of the factors affecting these parameters are very important.

Many authors observed that in a given population only some females can reproduce (L ew ontin \& Dunn, 1960; Petras, 1967; Bujal$\mathrm{s} \mathrm{k} \mathrm{a,} \mathrm{1970),} \mathrm{and} \mathrm{that} \mathrm{the} \mathrm{number} \mathrm{of} \mathrm{females} \mathrm{producing} \mathrm{litters} \mathrm{decreases}$ at a higher population density (Lloyd \& Christian, 1969). At a higher density the intervals between pregnancies become longer ( $\mathrm{R}$ o $\mathrm{m}$ a $\mathrm{n}$ \& Strong, 1962; Doolittle, 1967; Lloyd \& Christian, 1967).

* Praca została wykonana w ramach problemu węzłowego 09.1.7, koordynowanego przez Instytut Ekologii PAN. 
The population increase may be also regulated by changes in fertility of females ( $\mathrm{Cr}$ ow croft \& R owe, 1963). The factors mentioned above affect only production of young mice. However, the mortality of mice in the first days of their life is the most commonly recognized mechanism regulating population numbers (B r ow n, 1953; South wi ck, 1955; L l o y d \& Christian, 1969; W a l k o w a, 1971). The following factors may influence the mortality of young mice: increased aggressiveness between individuals (S o u thwick, 1955; A nderson, 1961; Crowcr of t \& R ow e, 1963; Petrusewicz, 1963; B a iley, 1966; Lloyd \& Christian, 1967) and insufficient or unsuitable maternal care (B rown, 1953; Southwick, 1955; Louch, 1956). Louch (1956) observed that at a higher population density females begin to transfer newborns from one nest house to another. He suspected that the increased frequency of transfer of young mice may unfavourably affect their survival but he neither provided experimental proof nor he attempted to analyze this phenomenon. The literature is lacking quantitative data explaining the effect of females on the mortality of juvenile mice. The purpose of the present study was to attempt the explanation of this effect.

\section{MATERIALS AND METHODS}

The experiment was carried out on 18 populations of the laboratory mouse. Each population was reared in a wooden cage $160 \times 40 \times 10 \mathrm{~cm}$. The top of the cage was covered with a wire net enabling observations of the animals. Water and food were supplied in excess. The food consisted mainly of MSL mixture supplemented with milk and wheat seedlings. A population was established by transferring into the cage 3-month old mice deriving from a stock reared for a dozen or so years after it had started from 4 pairs of siblings. The initial numbers in the population were 20,60 or 100 individuals. Within each numbers the populations differed in the proportion of sexes, $i . e$. the ratio of males to females was either $1: 1,1: 2$ or $1: 4$. Table 1 shows the scheme of the experiment. Each experiment was continued for 1 to 2 months.

Particular individuals were marked by amputation of external digits or by using a paint in a system of dots and strips on the mouse coat.

Each day the population was examined to establish the number of young mice (below 10 days of age) and on the following day the number of survivors was determined. The percentage of dead young mice in that period corresponded to the relative mortality per day. On this basis the mean percentage mortality for each week was calculated for particular experiments.

The number of pregnant females was estimated daily on the basis of their appearance and this enabled to establish the day of parturition. Since it is known that the mean length of pregnancy in mice amounts to 19.5 days (M y r h a, R y szkowski \& Walkowa, 1969) the day of fertilization could be calculated for each female. To specify precisely these data all females were sectioned at the end of the experiment and in pregnant females the occipital-gluteal length of one 
embryo was measured. Taking into account embryo length the stage of pregnancy was established ( $\mathrm{T}$ h eil e r, 1972).

Hence on the basis of daily appearance and final section at the end of experiment the period of pregnancy could be estimated for each female. In effect this enabled to determine the state of each female in particular days of the experiment and to distinguish three classes of females:

- pregnant - being in the second half of the pregnancy,

- lactating - up to 5 th day after parturition,

- others - non-lactating, non-pregnant, or being in the first half of the pregnancy period.

Separation of a distinct class of females in the second half of pregnancy. was suggested by the data of literature which indicated that the females before parturition show an aggressive behaviour toward newborns (B r o w n, 1953).

Percentage share of each class of females in the transfer of young mice was calculated. It corresponds to the percentage of transfers falling for one female in a given class in comparison with the total number of transfers by one female in this population.

Table 1

Scheme of the experiment.

\begin{tabular}{cccc}
\hline $\begin{array}{c}\text { Population } \\
\text { numbers }\end{array}$ & Sex ratio & $\begin{array}{c}\text { No. of analysed } \\
\text { populations }\end{array}$ & $\begin{array}{c}\text { No. of hours of } \\
\text { observations }\end{array}$ \\
\hline 100 & $1: 1$ & 2 & 20 \\
100 & $1: 4$ & 2 & 27 \\
60 & $1: 1$ & 1 & 15 \\
60 & $1: 2$ & 2 & 25 \\
60 & $1: 4$ & 6 & 70 \\
20 & $1: 1$ & 2 & 15 \\
20 & $1: 4$ & 3 & 30 \\
Total & & 18 & 202 \\
\hline
\end{tabular}

In order to obtain the data on frequency of transfers of young mice by females in a given population some observations were carried out at noon hours in the period of augmented reproduction, i.e. 18-20 days after starting the experiment. During these observations (jointly approximately 200 hours) the following facts were recorded:

- number of transfers of newborns by females in the unit of time,

- identification of females involved in transfer,

- behaviour of males.

In order to obtain the index of frequency of transfers of young mice by females the number of transfers observed during a day was calculated for $5 \mathrm{~min}$ for one young transferred individual. The frequency of transfers was calculated for one week periods, but these data were assembled for 16 populations only, since in the remaining two populations (numbering 20 and 100 individuals with the sex ratio $1: 1)$ the mortality of newborns was so high that the young mice remained alive only during the first day after birth when the observations were carried out. In effect in these two latter populations only one hour observations were made and the incomplete data could be only used for the analysis of percentage share of various categories of females involved in the transfer of newborns. 
When analysing some relationships the value of correlation coefficient $(r)$ was calculated. After ascertaining its significance (at $p=0.05$ ) the relationship was evaluated from the linear regression equation $(y=a x+b)$.

\section{RESULTS}

\subsection{Reproduction in the Investigated Populations}

It was asumed that the mean litter size, number of resorbed embryos and frequency of fertilization are the indices of reproduction in a population. The mean litter size in examined populations amounted to 8.0 individuals (maximum 9.0, minimum 7.8 in single cages) and showed no relationship with the population density. Resorption occurred sporadically in all examined populations independently of density. The resorption index defined as the ratio of the number of females in which cccurred the resorption of at least one embryo to the total number of examined females amounted on the average to 0.03 (maximum 0.08 , minimum 0 ).

The frequency of fertilization was estimated from the intervals (in days) between the end and beginning of consecutive pregnancies, and then the mean length of this period was calculated for all populations of a given density. $\mathrm{It}$ was found that the mean intervals between pregnancies increase with population numbers from 4.8 days at the population of 20 individuals to 7.2 days at 100 individuals (Table 2).

Table 2

Changes in the length of the mean interval between the end and beginning of consecutive pregnancies in females at different population numbers.

\begin{tabular}{cc}
\hline $\begin{array}{c}\text { Population } \\
\text { numbers }\end{array}$ & $\begin{array}{c}\text { Mean interval between } \\
\text { pregnancies, days }\end{array}$ \\
\hline 20 & 4.8 \\
60 & 5.5 \\
100 & 7.2 \\
\hline
\end{tabular}

Table 3

Relationship between frequency of transfer of young mice by females and population numbers.

\begin{tabular}{cc}
\hline $\begin{array}{c}\text { Population } \\
\text { numbers }\end{array}$ & $\begin{array}{c}\text { No. of transfers of young mice } \\
\text { per } \mathbf{5} \text { min per one newborn }\end{array}$ \\
\hline 20 & 0.092 \\
60 & 0.191 \\
100 & 0.513 \\
\hline
\end{tabular}

In the examined populations almost all females were fertilized and produced litters. The percentage of females not participating in the reproduction amounted on the average to $1 \%$ independently of population numbers (minimum $0 \%$, maximum $3 \%$ ).

\subsection{The Effect of Transfer of Young Mice on Their Mortality}

The observations indicated that young mice are transferred by adult individuals. The transfer is accomplished almost exclusively by females (during 200 hours of observations only 5 cases of males were recorded). 
The relationship between the frequency of transfer of young mice (number of transfers of one individual during $5 \mathrm{~min}$ ) and the number of females in the population was analyzed. It was found that such relationship exists, it is rectilinear and statistically significant $(r=0.6340$, $\mathrm{n}=16, y=0.0043 x+0.018$ ) (Fig. 1) The frequency of transfer changed from 0.065 at 20 females to 0.430 at 80 females.

In order to analyse the relationship between the frequency of transfer of young mice and population numbers the mean index was calculated for all populations of the same numbers (Table 3 ). The intensity of transfer increased from 0.092 at 20 individuals to 0.513 at 100 individuals per cage.

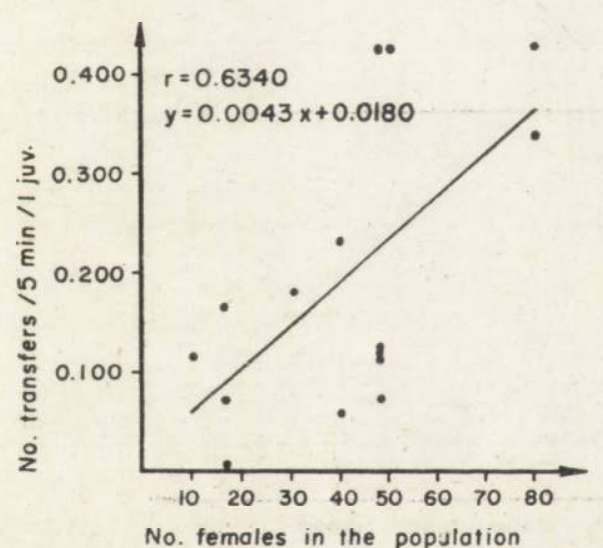

Fig. 1.

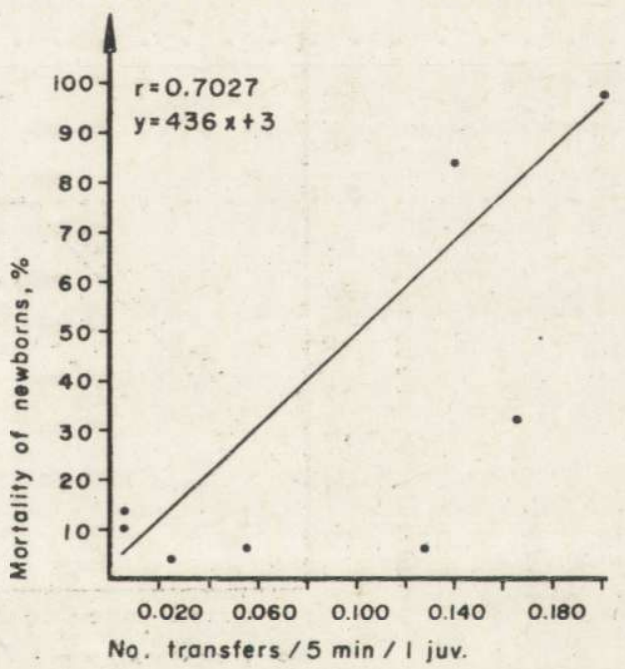

Fig. 2.

Fig. 1. Relationship between the number of females in the population and frequency of transfer of newborns by females.

Fig. 2. Relationship between mortality of young mice and frequency of their transfer by females in the populations of 20 individuals with the sex ratio of $1: 1$ and $1: 4$.

When analysing the relationship between the frequency of transfer of young mice by females and mortality of newborns it was found that at the population numbers of 20 and at all sex ratios (1:1 and $1: 4)$ such relationship exists (Fig. 2). It is directly proportional and statistically significant $(r=0.7027$ at $n=8, y=436 x+3)$. At population numbers of 20 individuals the mortality of young mice changes from $5 \%$ at the transfer index of 0.005 to $94 \%$ at the transfer index of 0.210 . The relationship between frequency of transfer of young mice and their mortality 
was also found in the population of 60 individuals, but only when the sex ratio was 1:4 (Fig. 3). Such relationship occurred at the transfer index ranging from 0.007 to 0.207 (correlation coefficient $r=0.6339$ at $\mathrm{n}=12$ and $y=213 x+20$ ). The mortality increased from $19 \%$ at minimum intensity of transfer to $79 \%$ at the transfer index of 0.207 . Further increase in the frequency of transfer did not affect mortality of young mice (mortality ranged from 45 to $100 \%$ ). At the population numbers of 60 and sex ratio of $1: 1$ and $1: 2$ no statistically significant correlation was observed between mortality and frequency transfer $(r=0.3755$ at $n=10)$.

Such relationship was also absent at the population number of 100 and sex ratio of $1: 1$ and $1: 4(r=0.0617, \mathrm{n}=10)$, but in this case mortality

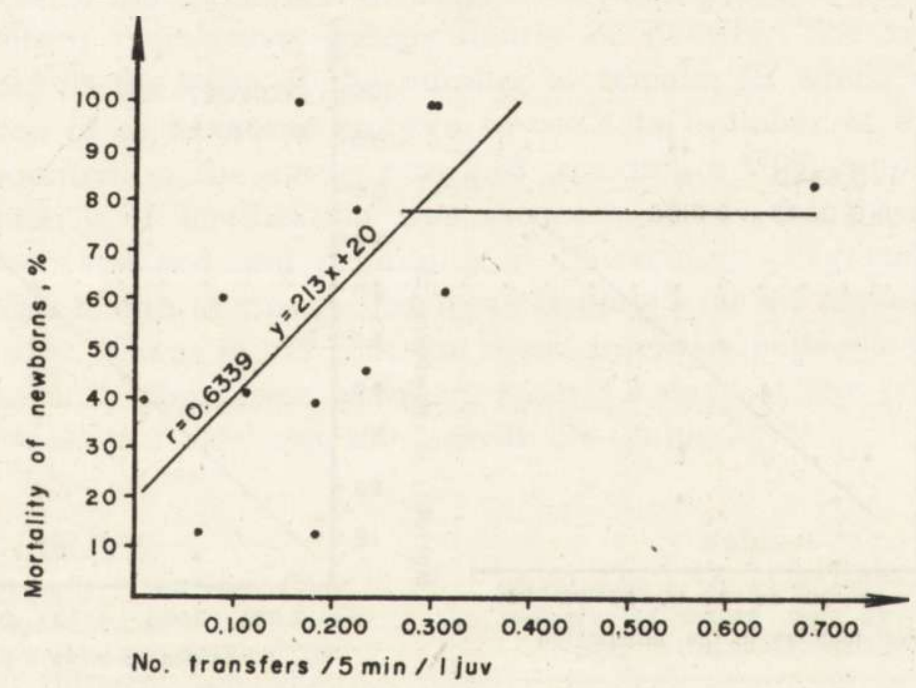

Fig. 3. Relationship between mortality of young mice and frequency of theic transfer by females in the population of 60 individuals with sex ratio of $1: 4$.

was close to $100 \%$ and frequency of transfer was very high (transfer index ranged from 0.131 to 0.527 ).

Hence the relationship between frequency of transfer of young mice and their mortality was found in the populations of 20 individuals and sex ratios equal to $1: 1$ and $1: 4$, as well as in the population of 60 and sex ratio of $1: 4$, when the number of males was low (below 12).

The observations indicated that young individuals are transferred by females belonging to all groups: lactating, pregnant and even others. The highest percentage share in the transfer was found for lactating females (Figs 4 and 5), this being probably related to increased instinct of maternal care. 
In order to establish the effect of population numbers on the participation of particular groups of females in the transfer of young mice the data were calculated as means for populations consisting of 20,60 or 100 individuals. At higher population numbers the percentage of non-lactating females participating in newborns transfer (including pregnant and other females) increases from $30 \%$ at 20 individuals to $45 \%$ at 100 individuals (Fig. 4). Moreover, participation of particular classes of females in the transfer of young mice at various sex ratio was investigated in order to calculate percentage share of lactating, pregnant and other females as

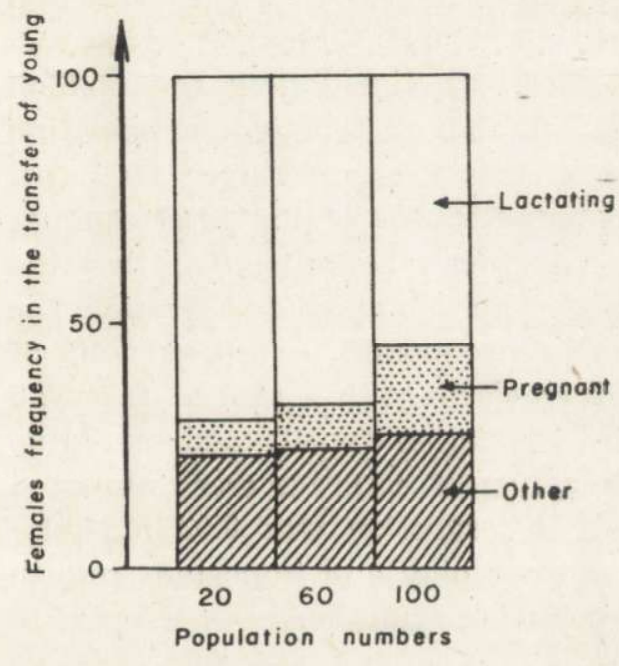

Fig. 4.

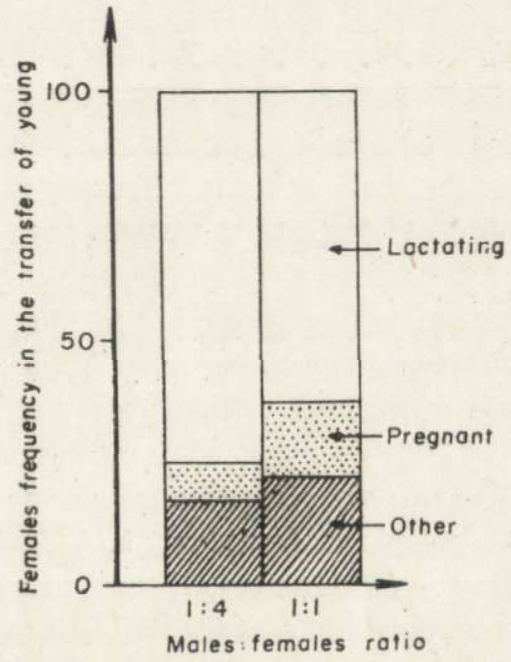

Fig. 5.

Fig. 4. Proportion of lactating, pregnant and other females in the transfer of young mice at various population numbers.

Fig. 5. Proportion of lactating, pregnant and other females in the transfer of young mice at various sex structure of the population.

the mean for all populations at the sex ratio of $1: 1$ and $1: 4$. The proportion of non-lactating females in the transfer of young mice increases at higher numbers of males and amounts on the average to $26 \%$ for all populations at the sex proportion $1: 4$ and to $39 \%$ for all populations at the sex ratio of $1: 1$ (Fig. 5). The analysis at the sex ratio $1: 2$ is not presented because in such populations only those numbering 60 individuals were fully examined while the data concerning 20 and 100 individuals are lacking. 


\section{DISCUSSION}

The investigated populations did not furnish any proof that population numbers are regulated by changes in the reproduction.

The analysis of the length of intervals between pregnancies in females shows that they are prolonged from 4.8 days in the populations of 20 individuals to 7.2 days at 100 individuals Hence at a 5 -fold increase of the population numbers a 1.5 -fold prolongation of the mean interval between pregnancies is observed. The difference in the length of these intervals ( 2.4 days) corresponds to only $1 / 8$ of the mean length of pregnancy in the laboratory mouse. Hence it appears that the frequency of fertilization could not exert any significant effect on the reduction of the population numbers. Le wont in \& D unn (1960), R e i m e r \& Petras (1967) and Lloyd \& Christian (1969) hold the opinion that at higher population densities the number of females participating in the reproduction decreases. In the studies presented here very few females did not produce any litter (from 0 to $3 \%$ of the total number of females in a given population). Thus it can be concluded that the regulation of the population density was not obtained by limiting the number of females participating in the reproduction. In all variants of the experiment the litter size was rather constant and ranged from 7.8 to 9.0 individuals, independently of the population density and sex ratio. Also no significant changes in the resorption of embryos were observed in pregnant females (the mean index of resorption was 0.03 independently of density). Hence this factor did not play any important role in the reproduction and could not affect population numbers.

Thus it can be concluded that in the examined populations their numbers were not regulated by reproduction while such function can be ascribed to mortality of young mice. The idea that in the population of the laboratory mouse the mortality of juvenile individuals is the main factor regulating numbers is supported by the observations of several authors (B rown, 1953; South wick, 1955; Lloyd \& Christian, 1969; W a $1 \mathrm{k}$ o w a, 1971).

Many investigators suggested that at food excess and lack of predators the regulation of population numbers depends mainly on the relationships existing between males: structure of domination, intensity of aggressiveness (Southwick, 1955; Anderson, 1961; Crowcroft \& Rowe, 1963; Petrusewicz, 1963, Bailey, 1966; Lloyd \& $\mathrm{C} h \mathrm{r}$ is t i a n, 1967). Intensive aggressiveness at a high population density causes changes in the behaviour of animals: insufficient maternal care -(B r own, 1953), construction of modified nests poorly adapted for protection of newborns, or destruction of nests (Southwick, 1955). 
Insufficient and inadequate maternal care leads to abandonment and trampling of newborns or to cannibalism (B r ow n, 1953; L o u c h, 1956; $\mathrm{S}$ o $\mathrm{uth}$ wick, 1955). Increased aggressiveness may also hinder feeding of young mice to such extent that they starve to death ( $\mathrm{C} \mathrm{hr}$ istia $\mathrm{n}$, 1956; Louch, 1956; Lloyd \& Christian, 1967). According to L ouch (1956) an important factor in the mortality of juvenile mice may also depend on direct acts of aggressiveness toward young mice immediately after leaving the nest.

The function of females in creating social structure is rather passive (Anderson \& Hill, 1965), but Reimer \& Petras (1967) observed that also females may actively defend the territory occupied by them. Rowe \& Crowcroft (1963) found that females become aggressive (even toward males from their own population) but only in the period of lactation. L o u ch (1956) supposes that the repeated transfer of newborns may increase their mortality.

The present study indicates that females affect the mortality of juvenile mice since the relationship has been demonstrated between the frequency of newborn transfer by females and mortality of newborns. The transfer of young mice by adult individuals does not cause directly their death. On the other hand, repeated transfer leads to abandonment of newborns which are trampled and deprived of food and hence may die in effect of physical trauma or starvation. The relationship between transfer of young mice and their martality has not been ascertained in all populations. According to Petrusewicz (1963) each population develops a definite and characteristic structure: relationships between individuals, social hierarchy, care about the offspring, etc. This has been confirmed by the studies of W a l k ow a \& P e tr u s e w i c z (1967) and W a lkowa (1971), which indicated that even in the populations of identical initial numbers and reared in identical conditions there appear significant differences in production. Perhaps the lack of the relationship between frequency of transfer of young mice and their mortality observed in some populations but its occurrence in other populations is consequence of various kinds of organization in these populations. The relationship between frequency of transfer and mortality was observed only in the populations with a low number of males - up to 12 (Figs 2 and 3). It can be supposed that at small number of males the principal factor responsible for newborn mortality is associated with the behaviour of females (changed at high population density), whereas at higher number of males they begin to play more important role in juvenile mortality and in such way conceal the effect of females.

The data concerning participation of particular classes of females in the transfer of young mice showed the existence of differences between 
populations of various numbers and various sex ratio. In general, the highest share in the transfer of young mice was observed for lactating females. At increased population numbers and lower proportion of females the non-lactating females were significantly involved in the transfer of young mice (Figs 4 and 5). Participation of non-lactating females in the maternal "care " at high population densities results in the increased unrest in the population, and increased frequency of transfer leading to pulling out, abandonment and trampling of newborns. In such way the instinct, which in nature should serve to increase the survival of newborns, may at high population densities become one of the factors limiting population growth.

The populations were examined only in the initial stage of their existence in order to simplify the experiment. After 20 days from the beginning of the population and for the next two weeks a significant number of newborns appear daily. At later periods production of litters by females is less synchronous and in some days no birth was noted this increased the amount of work required for collecting materials. It can be supposed that the observed phenomena may be extrapolated for longer periods of existence of populations. However, this requires further studies which appear promising on the ground of the results obtained in the presented experiments.

Acknowledgements: The author wishes to thank Dr. Wiera Walkowa and Dr. Roman Andrzejewski for help, guidance and valuable substantial and methodic suggestions in the course of the present study.

\section{REFERENCES}

1. A nders on P. K., 1961: Density social structure and non-social environment in house-mouse populations and the implication for regulation of number. Trans. N.Y. Acad. Sci., 23: 447-457.

2. Anderson P. K. \& Hill J. L., 1965: Mus musculus: experimental induction of territory formation. Science, 148: 1753-1755.

3. Bailey E. D., 1966: Social interaction as a population-regulating mechanism in mice. Canad. J. Zool., 44, 6: 1007-1012.

4. Bujalska G., 1970: Reproduction stabilizing elements in an island populations of Clethrionomys glareolus (S chreber, 1780) Acta theriol., 15, 25: $381-412$.

5. Brown R. Z., 1953: Social behaviour reproduction and population changes in the house mouse (Mus musculus L.). Ecol. Monogr., 23: 217-240.

6. Christian J. J., 1956: Adrenal and reproductive responses to population size in mice from freely growing populations. Ecology, 37, 2: 258-274.

7. Crowcroft P. \& Rowe F. P., 1963: Social organization and territorial behaviour in the wild house mouse (Mus musculus L.). Proc. zool. Soc., Lond., 140: $517-531$.

8. Doolittle D. P., New M. L. \& Sheps M. C., 1967: Biologic determinant of birth intervals in mice. Fertil. Steril., 18: $381-392$. 
9. L e wontin R. C. \& Dunn L. C., 1960: The evolutionary dynamics of a polymorphism in the house mouse. Genetics, 45: 705-722.

10. Lloyd J. A. \& Christian J. J., 1967: Relationship of activity and aggression to density in two confined population of house mice (M. musculus). J. Mammal., 48, 2: 262-269.

11. Lloy d J. A. \& Christian J. J., 1969: Reproductive activity of individual females in three experimental freely growing populations of house mice (Mus musculus) J. Mammal., 50, 1: 49-59.

12. Louch C. D., 1956: Adrenocortical activity in relation to the density and dynamics of three confined populations of Microtus pensylvanicus. Ecology, 37: $307-313$.

13. Myrcha A., Ryszkowski L. \& Walkowa W., 1969: Bioenergetics of pregnancy and lactation in white mouse. Acta theriol., 14, 12: 161-166.

14. Petrusewicz K., 1963: Population growth induced by disturbance in the ecological structure of the population. Ekol. pol A, 11, 3: 87-124.

15. R e imer J. D. \& P etra s M. L., 1967: Breeding structure of the house mouse, Mus musculus, in a population cage. J. Mammal., 48: 88-99.

16. Roman L. \& Strong L. C., 1962: Age, gestation, mortality and litter size in mice. J. Gerontol., 17: 37-39.

17. Southwick C. H., 1955: The population dynamics of confined house mice supplied with unlimited food. Ecology 36, 2: 212-225.

18. Southwick C. H., 1955a: Regulatory mechanisms of house mouse population: social behavior affecting litter survival. Ecology 36, 4: 627-634.

19. Theiler K., 1972: The house mouse. Development and normal stages from fertilization to 4 weeks of age. Springer-Verlag: 1-168. Berlin.

20. W a $1 \mathrm{kowa}$ W., 1971: The effect of exploitation on the productivity of laboratory mouse populations. Acta theriol., 16, 19: 295-328.

21. Walkowa W. \& Petrusewicz K., 1967: Net production of confined mouse populations. [In: "Secondary productivity of terrestrial ecosystems", Ed. K. Petrusewicz]. 1: 335-347. Polish. Sci. Publ., Warszawa-Kraków.

Accepted, January 8, 1976.

\section{ANNA KOZAKIEWICZ}

\section{WPEYW ZAGESZCZENIA I PROPORCJI PECI NA SMIERTELNOSC MEODZIEŻY W EKSPERYMENTALNYCH POPULACJACH MYSZY \\ LABORATORYJNEJ}

\section{Streszczenie}

Eksperyment przeprowadzono na osiemnastu populacjach myszy laboratoryjnej. Pokarm i wodę podawano w nadmiarze. Wyjściowa liczebność populacji wynosiła 20,60, 100 osobników, przy czym w obrębie każdej liczebności były populacje o różnej proporcji płci tzn. stosunek liczby samców do samic wynosił 1:1, 1:2 lub 1:4 (Tabela 1). Codziennie na podstawie oględzin sprawdzano stan samic, wyróżniając 3 kategorie: ciężarne, karmiące i inne, a po likwidacji eksperymentu dokonywano sekcji samic, mierząc embriony i sprawdzając liczbę zresorbowanych płodów. Dia każdego đnia obliczono procentową śmiertelność myszy w wieku do 10 
dni. Na podstawie danych otrzymanych z codziennych obserwacji, obliczono wskaźnik częstości przenoszenia młodych myszy (liczba przeniesień/5 min./1 młodego osobnika).

Nie stwierdzono, aby badane populacje były limitowane przez zmiany w rozrodczości: liczba samic nie biorących udziału w rozrodzie była nieznaczna i niezależna od zagęszczenia. Podobnie niezależny od_zagęszczenia był wskaźnik resorpcji pło. dów, jak i średnia wielkość miotu. Odstępy pomiędzy poszczególnymi ciążami u samic wzrastały nieznacznie wraz z zagęszczeniem (Tabela 2).

Stwierdzono, że częstość przenoszenia młodych myszy przeż samice zależy wprost proporcjonalnie od liczebności populacji (Tabela 3) oraz liczby samic w populacji (Ryc. 1).

Istnieje wprost proporcjonalna zależność między śmiertelnością młodych myszy, a częstością przenoszenia ich przez samice w populacjach o liczebności 20 osobników przy proporcji płci $1: 1$ i $1: 4$ oraz 60 osobników i proporcji płci $1: 4$, a więc wtedy gdy w populacji jest mało samców - do 12 (Ryc. 2 i 3). Gdy samców jest więcej (liczebność 60 osobników i proporcja płci $1: 1,1: 2$ oraz 100 osobników proporcja płci $1: 1,1: 4)$ zależności takiej nie stwierdzono, \ale śmiertelność w tych przypadkach była bliska $100 \%$, a częstość przenoszenia młodych myszy układała się na wysokim poziomie.

Przy wzroście liczebności populacji oraz stosunkowo małej liczbie samic, zwiększa się udział samic niekarmiących w przenoszeniu młodych myszy (Ryc. 4 i 5). 